\title{
Finite Element Analysis of Impact Energy on Spur Gear
}

\author{
Ismail Ali Bin Abdul Aziz ${ }^{1}$, Daing Mohamad Nafiz Bin Daing Idris ${ }^{1,}$, , Mohd Hasnun Arif \\ Bin Hassan ${ }^{1}$, Mohamad Firdaus Bin Basrawi ${ }^{1}$ \\ ${ }^{1}$ Faculty of Mechanical Engineering, Universiti Malaysia Pahang, 26600 Pekan Pahang.
}

\begin{abstract}
In high-speed gear drive and power transmission, system impact failure mode always occurs due to the sudden impact and shock loading during the system in running. Therefore, study on the amount of impact energy that can be absorbed by a gear is vital. Impact test equipment has been designed and modelled for the purpose to study the impact energy on gear tooth. This paper mainly focused on Finite Element Analysis (FEA) of impact energy that occurred during simulation involving the impact test equipment modelling. The simulation was conducted using Abaqus software on critical parts of the test equipment to simulate the impact event and generate impact data for analysis. The load cell in the model was assumed to be free fall at a certain height which gives impact load to the test gear. Three different type of material for the test gear were set up in this simulation. Results from the simulation show that each material possesses different impact energy characteristic. Impact energy values increased along with the height of load drop. AISI 1040 were found to be the toughest material at $3.0 \mathrm{~m}$ drop that could withstand up to $44.87 \mathrm{~N}$.m of impact energy. These data will be used to validate data in physical experiments in further study.
\end{abstract}

\section{Introduction}

Impact test commonly used to study the toughness and strength of materials. Syafiqah Nur Azri et. al [1] had come to a conclusion, fracture often occurs at the impacted zone where compression was more dominant in high-velocity impact, differ for low- velocity impact, invisible cracks often occur but cannot be seen using the naked eyes. There was several impact test equipment that often used by researchers to investigate factors for the ability of the materials to absorb energy during deformation or fracture of material's toughness that includes drop weight impact test, Charpy and Izod impact test [2-5]. Drop weight impact test could be either an instrumented or non-instrumented test machine [6].

There is one common gear failure from the regular mode that caused the gear to fail which is impact failure[8]. Tooth bending, tooth shear, tooth chipping, case crushing and torsional shear are usually found in impact failure. There was some cause which referring to this impact failure. These include the improper gear assembly, poor gear set design, shock load or foreign object falls into the gearing sets Advanced developments in the finite element method (FEM) makes most researchers are now more likely to perform finite element method in advance for data verification purposes [9-11].

\footnotetext{
*Corresponding author: daingnafiz@ump.edu.my,
} 


\section{Equipment Design}

\subsection{Test Gear}

Set of test gears were designed and used for the simulation study. Table 2 shows the geometry of the gear used in this study. The gear has been designed based on module $(m) 4$ $\mathrm{mm}$, pressure angle $\left(\alpha_{0}\right) 20^{\circ}$ with 18 number of teeth. There were three types of materials were used in this simulation that includes AISI 1040, AISI 3215 and AISI 4140.

Figure 2 show the test gear design. It was designed to have the addendum circle of 80 $\mathrm{mm}$, pitch circle $72 \mathrm{~mm}$ and for the dedendum circle, it was designed to have $9 \mathrm{~mm}$ from the addendum circle.

Table 2. Bills of Material for Impact Test Equipment

\begin{tabular}{lcc}
\hline \multicolumn{1}{c}{ Profile } & Details \\
\hline Number of teeth & 18 \\
Module & $m$ & $4 \mathrm{~mm}$ \\
Pressure Angle & $\alpha_{0}$ & $20^{\circ}$ \\
Face width & $\beta$ & $10 \mathrm{~mm}$ \\
Materials & & AISI 1040, AISI 3215, \\
& & AISI 4140 \\
\hline
\end{tabular}

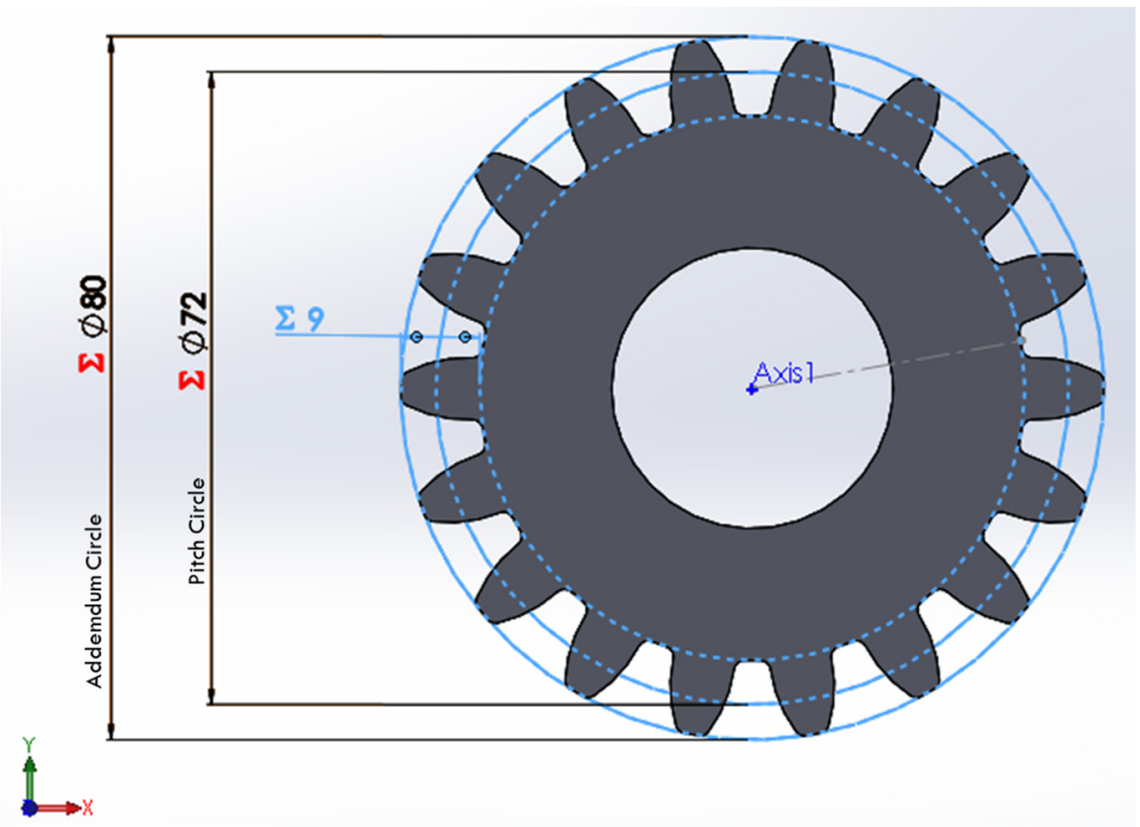

Fig. 2. Design of test gear 
The model was assumed to be free fall at a certain height which gives impact load to the testing gear. The process flow of constructing Abaqus Simulation was simplified in Figure 3: Process flow in developing simulation model analysis using Abaqus. Before creating FEM analysis, the understanding of process scenario needs to be done to ensure the simulation will create an exact scenario during the test. Misunderstandings will affect the result of the simulation. The first step before proceed to simulation was the configuration of the parts for the impact test equipment for the spur gear.

In this simulation study, only most critical parts of the test equipment were assembled. This will reduce the component simulation time, component contact, interaction, and meshing for the study. Critical parts that include gear assembly and impactor assembly (load cell and load bar), it was treated as deformable parts.

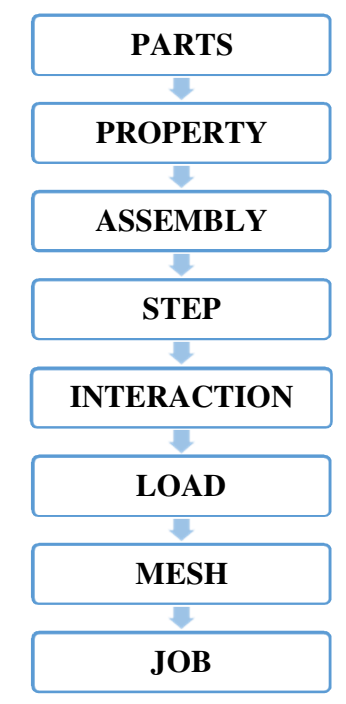

Fig. 3. Process flow in developing simulation model analysis using Abaqus

Table 3. Test gear material properties

\begin{tabular}{cccccc}
\hline Material & $\begin{array}{c}\text { AISI } \\
\mathbf{1 0 4 0}\end{array}$ & $\begin{array}{c}\text { AISI } \\
\mathbf{3 2 1 5}\end{array}$ & $\begin{array}{c}\text { AISI } \\
\mathbf{4 1 4 0}\end{array}$ & $\begin{array}{c}\text { AISI } \\
\mathbf{1 0 5 0}\end{array}$ & $\mathbf{A 3 1 6}$ \\
\hline $\begin{array}{c}\text { Density, } \rho \\
\left(\mathrm{kg} / \mathrm{m}^{3}\right)\end{array}$ & 7845 & 7700 & 7850 & 7850 & 8000 \\
$\begin{array}{c}\text { Young } \\
\text { Modulus, } \mathrm{E} \\
(\mathrm{GPa})\end{array}$ & 206 & 200 & 210 & 210 & 193 \\
$\begin{array}{c}\text { Yield } \\
\text { Strength, } \sigma_{\mathrm{y}}\end{array}$ & 415 & 450 & 415 & 580 & 205 \\
$\quad($ MPa $)$ & & 0.29 & 0.29 & 0.29 & 0.29 \\
$\begin{array}{c}\text { Poisson } \\
\text { Ratio }\end{array}$ & 0.29 & 0.29 & & \\
\hline
\end{tabular}

Property for each material such as density and elasticity must be exactly same to the unit used for part dimension. Thus, all property should be converted into $\mathrm{mm}$. For this project, the 
interest was to study the displacements and impact energy absorbed by the gear tooth during the impact event. Test gear material properties such as Density, Young Modulus, Yield Strength and Poisson ratio for the simulation study as shown in Table 3.

The velocity of the load cell can be defined inside the predefined field below the boundary condition tab. Then it comes to the mesh module. In here all part can be mesh using automatic mesh inside the mesh part instant tab. Complete mesh assembly was illustrated in Figure 5.

Step time as shown in Table 4 was calculated by dividing the displacement (desired height) and load cell velocity as express in equation (8). The value of velocity was calculated with equation (4).

$$
\mathrm{t}=\frac{S}{V}
$$

Where;

$$
\begin{aligned}
& t=\text { time }(\mathrm{s}) \\
& S=\operatorname{Displacement}(\mathrm{mm}) \\
& V=\operatorname{Velocity}(\mathrm{mm} / \mathrm{s})
\end{aligned}
$$

Table 4. Step time for every height

\begin{tabular}{ccc}
\hline $\begin{array}{c}\text { Height } \\
(\mathrm{mm})\end{array}$ & Velocity $(\mathrm{mm} / \mathrm{s})$ & Time $(\mathrm{s})$ \\
\hline 800 & 3962 & 0.20 \\
1800 & 5943 & 0.30 \\
2800 & 7412 & 0.38 \\
\hline
\end{tabular}

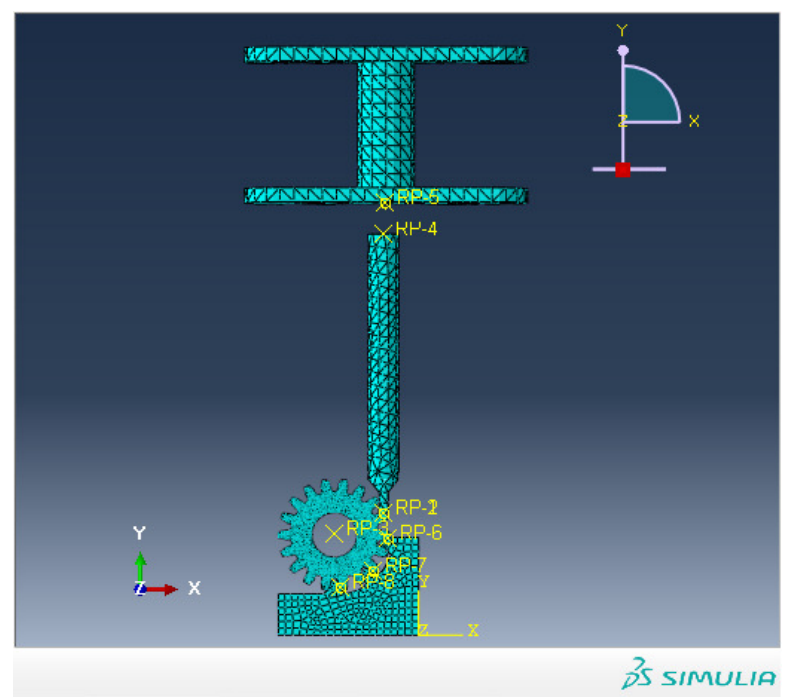

Fig. 5. Meshing assembly for simulation study 


\section{FEA Results from Abaqus}

\subsection{Illustrations of stress distribution for 3.0m Drop Height}

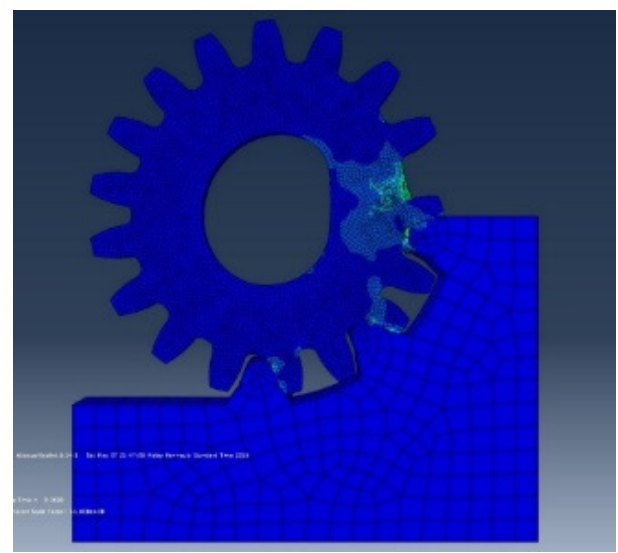

(a)

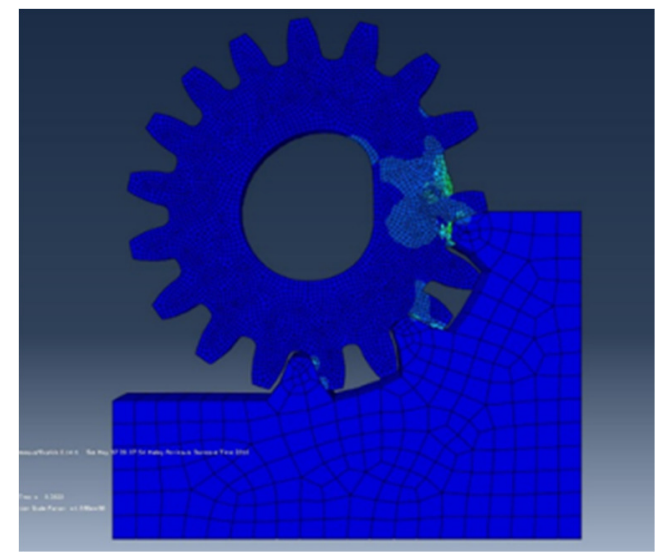

(b)

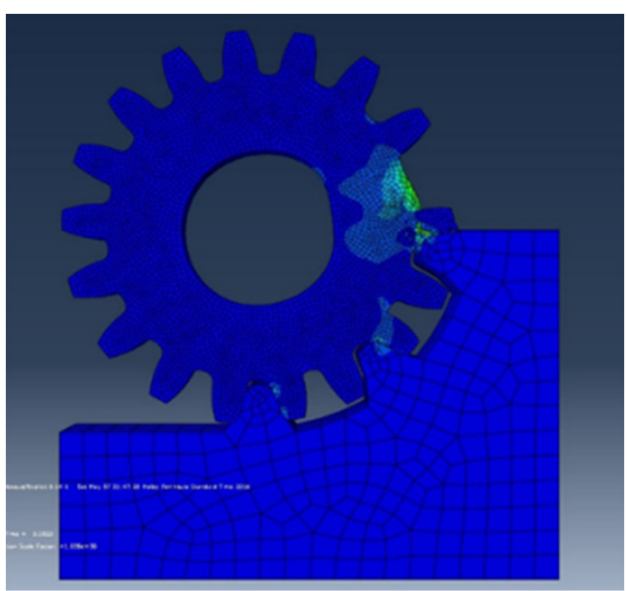

(c)

Fig. 10. Illustrations of stress distribution on testing gear for 3.0m drop height; (a) AISI 3215; (b) AISI 4140; (c) AISI 1040

Figure 10 shows the stress distribution for 3.0m drop height. From the illustration, the testing tooth already distorts excessively. This may be due to increasing of impact force to the testing due that cause the tooth fracture. 


\subsection{Illustrations of displacement on test gear for 3.0m Drop Height}

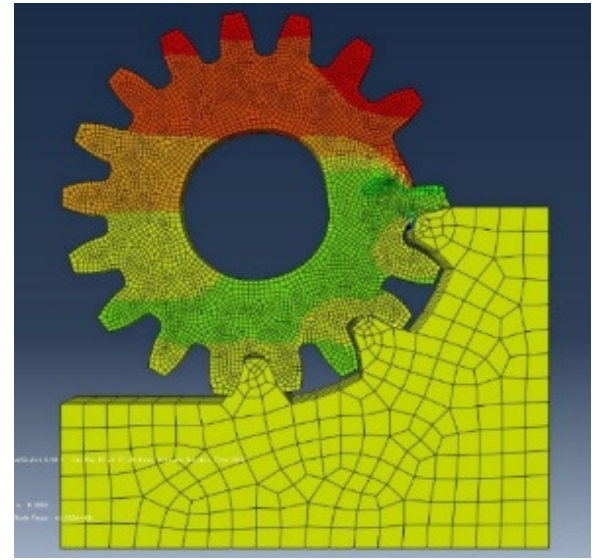

(a)

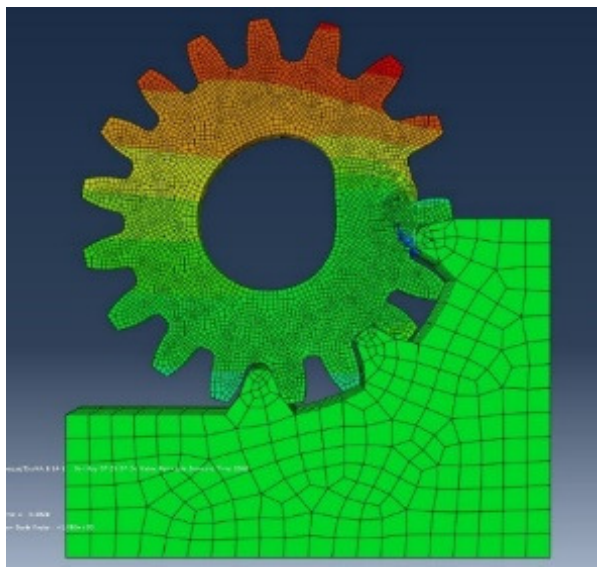

(b)

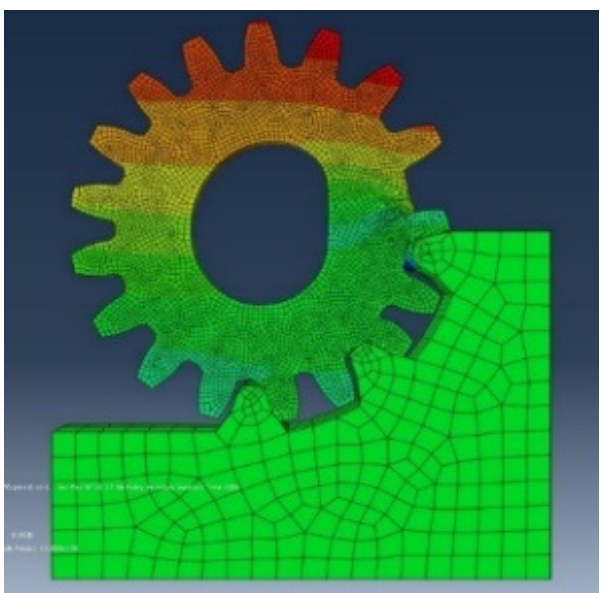

(c)

Fig. 11. Illustrations of displacement on testing gear for 3.0m drop height; (a) AISI 3215; (b) AISI 4140; (c) AISI 1040

The deformation of gear has been displayed in Figure 11. Red colour represents the high deformation occur while the blue colour represents the smallest deformation. AISI 3215 show the extreme deformation in tensile while no deformation in compression area.

\section{Discussions}

Results from Abaqus simulations were focused on the impact energy produced from the load being dropped and effects on the displacement of gear tooth. Three different load heights simulated in this study involving a height of 1.0 meter, 2.0meters and 3.0meter from the striker. There were three types of materials used in this simulation to make a comparison on displacement for each of the materials used. 
To show material comparisons, Figure 15 shows a compilation of all three earlier graph. From here we could see that only AISI 3215 had decreased reading between $1.0 \mathrm{~m}$ drop to $2.0 \mathrm{~m}$ drop. From here also shows that AISI 3215 was the weakest material that absorbs maximum impact energy at 28.05 N.m before starts to deform. Although AISI 1040 seem to be the toughest material that had maximum impact energy absorbed at 44.87 N.m, AISI 4140 was slightly lower at 43.43 N.m.

Another comparison we could see in Table 5 that show the impact energy for all materials at different height of load. At $1.0 \mathrm{~m}$ drop, mostly all material absorbs almost same reading at 8.8 N.m. At $1.0 \mathrm{~m}$ drop, AISI 3215 show decreasing reading to 6.877 N.m meanwhile AISI 1040 shows increasing reading to 11.309 N.m. Assuming AISI 1040 was the toughest material at 3.0m drop with a reading of 44.874 N.m and AISI 3215 was the weakest one with only 28.053 N.m before it starts to deform or fail.

Table 6 shows data on the displacement of a single tooth from a different height of load. From the table clearly shows the effects of different load to displacement. The higher load cell was set up to fall, the bigger reading in displacement will occur. However, for all three material used in the simulation, there was smaller different reading between $1.0 \mathrm{~m}$ to $2.0 \mathrm{~m}$ drop compared to $3.0 \mathrm{~m}$ drop

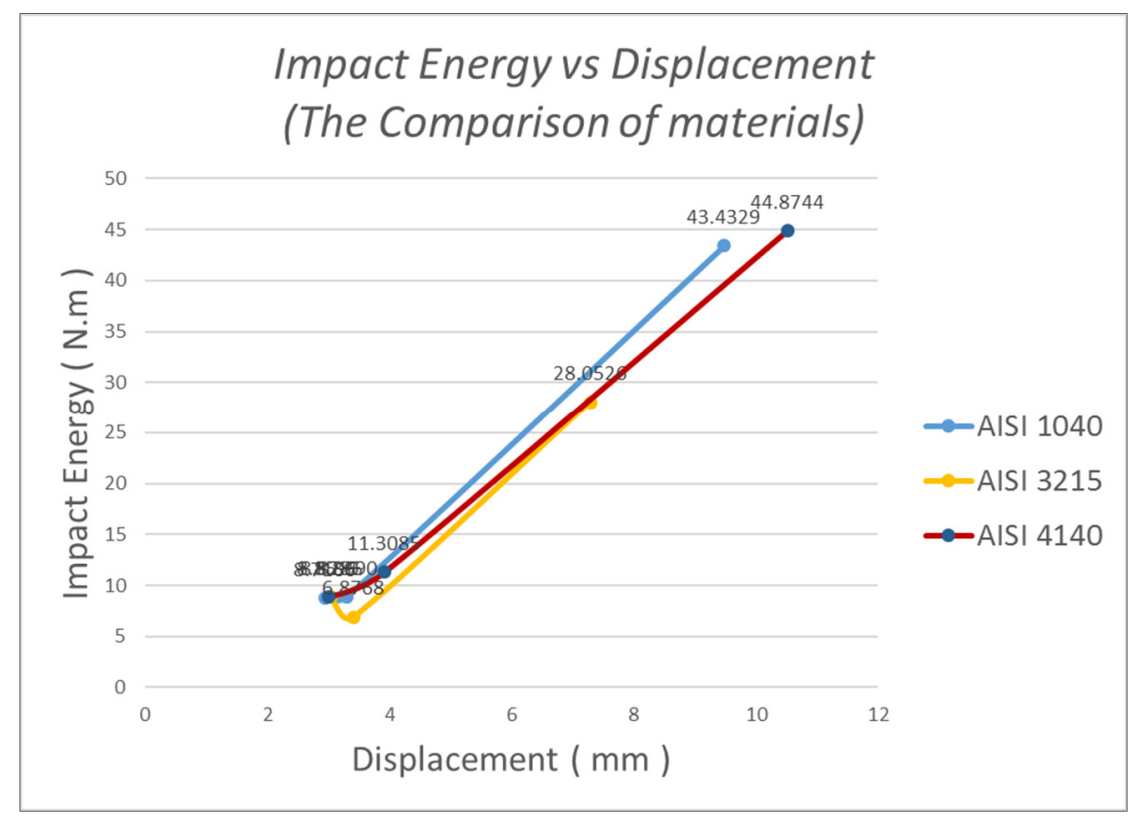

Fig. 15. Comparisons of Impact Energy - Displacement 
Table 5. Impact energy from different height of load

\begin{tabular}{cccc}
\hline \multirow{2}{*}{ Material } & \multicolumn{3}{c}{ Impact Energy (N.m) } \\
\cline { 2 - 4 } & $\begin{array}{l}1.0 \mathrm{~m} \\
\text { drop }\end{array}$ & $\begin{array}{c}2.0 \mathrm{~m} \\
\text { drop }\end{array}$ & $\begin{array}{c}3.0 \mathrm{~m} \\
\text { drop }\end{array}$ \\
\hline AISI 4140 & 8.720 & 8.870 & 43.433 \\
AISI 3215 & 8.829 & 6.877 & 28.053 \\
AISI 1040 & 8.852 & 11.309 & 44.874 \\
\hline
\end{tabular}

Table 6. Displacement of single tooth from different height of load

\begin{tabular}{cccc}
\hline \multirow{2}{*}{ Material } & \multicolumn{3}{c}{ Displacement (mm) } \\
\cline { 2 - 4 } & $\begin{array}{l}1.0 \mathrm{~m} \\
\text { drop }\end{array}$ & $\begin{array}{l}2.0 \mathrm{~m} \\
\text { drop }\end{array}$ & $\begin{array}{c}3.0 \mathrm{~m} \\
\text { drop }\end{array}$ \\
\hline AISI 4140 & 2.941 & 3.303 & 9.480 \\
AISI 3215 & 3.047 & 3.404 & 7.289 \\
AISI 1040 & 2.996 & 3.920 & 10.517 \\
\hline
\end{tabular}

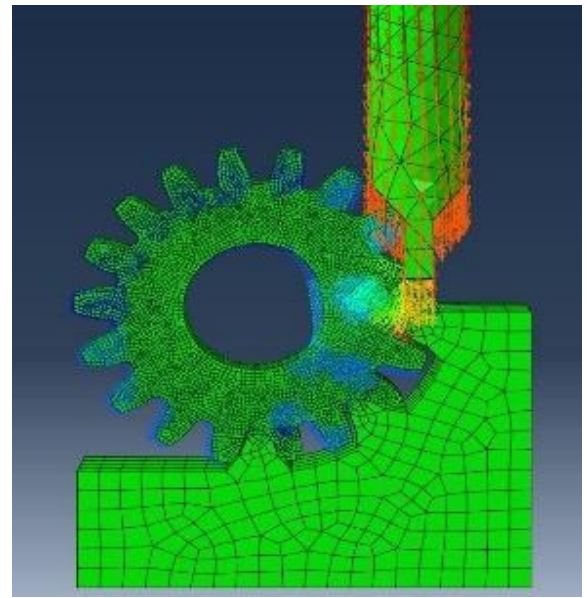

(a)

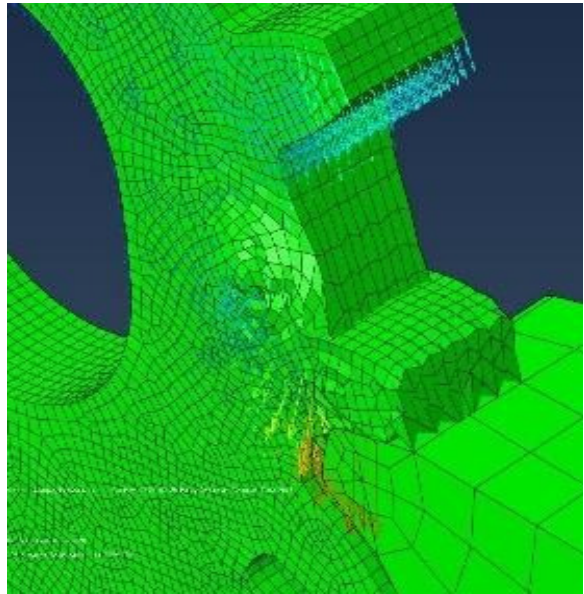

(b)

Fig. 16. Effect on impact to testing gear in simulation study (a) Displacement distribution during impact event; (b) Zoom view to affected tooth.

\section{Conclusion}

Impact energy - Displacement graph explained about the maximum limit of impact energy before undergoing displacement when tested on different heights. The focus of this result was to know the amount of impact energy exerted before deformation occurs at a different height. When the load bar impacts the testing gear tooth, the tooth will absorb the impact energy until it yields. At the moment, the specimen will start to undergo plastic deformation at the critical point of spur gear's tooth (Hofer's critical location for spur gear). The tooth 
continues to absorb energy and work harden at the plastic zone. When it reaches its limit (maximum point), it starts to deform until the tooth fracture. The distribution of deformation during impact simulation illustrate in Figure 16.

Based on simulation conducted, each material possesses different impact energy characteristic. As increase, the height of drop, the velocity of load cell also increases which cause increasing in impact energy. For $1.0 \mathrm{~m}$ drop height, most of the materials show the similar maximum point for impact energy which about 8.8 N.m. A different scenario occured when the drop height increased to $2.0 \mathrm{~m}$ (medium impact test).

Maximum point for each material can clearly define where AISI 1040 shows the toughest material where it required about $11.3 \mathrm{~N}$.m before undergoes plastic deformation. AISI 3215 shows the lowest value of impact energy were at 6.9 N.m. The significant result can be seen for AISI 1040 and AISI 3215 materials at 3.0m drop height (fast impact test), where at 28.1 N.m impact energy, AISI 3215 already reach its maximum point then start to deform, compared to AISI 1040 which required 44.9 N.m impact energy before deformation occur.

From this simulation data, increasing of height will increase the impact energy to each material. All these data will then be used to validate data obtained in physical experiments that will be carried out in near further study.

These works done under enormous support from Faculty of Mechanical Engineering, Universiti Malaysia Pahang with the grant no. RDU 1403132. The authors gratefully acknowledge the support given throughout this project.

\section{References}

1. S.N.A. Safri, M.T.H.S., N. Yidris, and F. Mustapha, Int. J.Eng. Sci., 3(9): p. 50 - 60 (2014)

2. Tanks, J., S. Sharp, and D. Harris, Polym. Test., 51: p. $63-68$ (2016)

3. Shin, H.-S. and B.J. Tuazon, Int. J. Impact Eng., 84: p. 124-133 (2015)

4. Hufenbach, W., et al., Compos. Sci. Technol., 68(12): p. 2391-2400 (2008)

5. F.M Shuaeib, et al., Pertanika J. Sci. Technol., 12(2): p. 159 - 175 (2004)

6. Duell, J.M., Impact Testing of Advanced Composites. Advanced Topics in Characterization of Composites, 97: p. 97 - 112 (2004)

7. Hangai, Y., et al., Mater. Sci. Eng.: A, 639: p. 597- 603 (2015)

8. Alban, L.E., Systematic analysis of gear failures. ASM International (1985)

9. Chen, Z., and Y. Shao, Eng. Fail. Anal., 18(8): p. 2149-2164 (2011)

10. Giner, E., et al., Eng. Fract. Mech., 76(3): p. 347-368 (2009)

11. Chang, C.-L., and S.-H. Yang, Eng. Fail. Anal., 16(5): p. 1711-1719 (2009)

12. Jabbour, T. and G. Asmar, Mech. Mach. Theory, 92: p. 375-390 (2015)

13. Silori, P., et al., Mater. Today-Proc., 2(4-5): p. 2236-2245 (2015)

14. González, E.V., et al., Compos. Struct., 94(11): p. 3364-3378 (2012)

15. Yoon, J.-Y. and B. Kim, Energies, 8(8): p. 8924-8944 (2015)

16. Colakoglu, A. and R. Yildirim, Model. Meas. Control B, 51: p. 19-19 (1993)

17. Shuaeib, F.M., et al., Pertanika J. Sci. Technol., 12(2): p. 159-175 (2004) 